\title{
Red reflex technique training simulator in newborns
}

\author{
Simulador para o treinamento da técnica do reflexo vermelho em recém-nascidos
}

\author{
Mauricio Leonardi da Silva Dias ${ }^{1}$ (1) $\mid$ mauricioleonardi@hotmail.com \\ Danilo Jun Kadosaki' (D) dankadosaki@gmail.com \\ Igor Santos de Souza² (D) igorsdsouza@gmail.com \\ Joacy Pedro Franco David ${ }^{3}$ (D) joacydavid@outlook.com \\ Ivete Furtado Ribeiro Caldas' (D) ivetecaldas@uepa.br \\ Rafael Oliveira Chaves ${ }^{3}$ (D) $\mid$ rafael.ufpa@gmail.com
}

\begin{abstract}
Introduction: The Red Reflex Test (RRT) consists of visualizing the reflection that light causes in the retina when it passes through the pupil. It is a screening test for pathologies that can lead to blindness, which still have great social and economic impact on families and the government. Teaching through simulators allows students and health professionals to acquire and improve their clinical skills.

Objective: The aim of the study is to develop a low-cost dummy, 3D printed and based on the Arduino platform, for the training of the red reflex technique (RRT) in newborns and evaluate its educational effectiveness.

Method: A RRT dummy was presented to 7 expert judges: 6 pediatricians and 1 ophthalmologist to evaluate its applicability in medical learning. For this purpose, they used a 14-item Likert scale of 5 points. Subsequently, 40 individuals participated in a course: 33 medical students, 5 pediatric residents, a nurse and a general physician. The participants were randomly assigned to two groups: control (CG) and experimental (EG) group. Each group consisted of 20 participants. The EG went through 4 stages: 1) theoretical background; 2) handling of the simulator; 3) simulated clinical practice and; 4) evaluation in real-life patients. Whereas the CG went through the following teaching methodological processes: 1) theoretical background; 2) direct training in real-life patients and; 4) practical evaluation in a real-life patient. After each respective group intervention, both groups were assessed on their learning in 40 newborns at Santa Casa de Misericórdia do Pará Foundation in Belém, state of Pará, Brazil.

Results: At the judges' evaluation regarding the simulator positive items (design, similarity, interest, relevance, content, memorization, didactics, previous reminiscence, comprehension and application), 49.2\% answered 'strongly agree' and 44.4\%, 'agree'. Regarding the negative questions (difficulty in understanding, information overload, abstraction, difficulty in handling and clarity of operation), $40.0 \%$ answered 'strongly disagree', and $57.1 \%$, 'disagree'. The judges were $94.9 \%$ favorable to the use of the simulator in medical education. However, comparing the two groups of students, regarding the time of exam, the results showed no statistically significant difference ( $p$-value $=0.29$ ).
\end{abstract}

Conclusions: The dummy showed its applicability for the learning of RRT, with the advantage of being able to perform the exam without having to disturb a real-life patient.

Keywords: Disease Prevention; Neonatal Screening; Simulation Training; Medical Education.

\section{RESUMO}

Introdução: O Teste do Reflexo Vermelho (TRV) consiste em visualizar o reflexo que a luz causa na retina ao passar pela pupila. Dessa forma, o TRV tria patologias que levam à cegueira e pode reduzir o impacto social e econômico das famílias e do governo. O ensino por meio de simuladores permite que estudantes e profissionais de saúde adquiram e melhorem as habilidades clínicas.

Objetivos: Este estudo teve como objetivos desenvolver um manequim de baixo custo, impresso em 3D e baseado na plataforma Arduino, para o treinamento do TRV em recém-nascidos e avaliar a eficácia educacional desse exame.

Métodos: Um manequim do TRV foi apresentado a sete juízes especialistas - seis pediatras e um oftalmologista - que avaliaram a aplicabilidade do teste na aprendizagem médica. Para isso, utilizaram a escala Likert de 14 itens de 5 pontos. Posteriormente, 40 participantes participaram de um curso: 33 estudantes de Medicina, cinco residentes em pediatria, uma enfermeira e um médico generalista. Dividiram-se aleatoriamente os participantes em dois grupos: controle (GC) e experimental (GE). Cada grupo foi composto por 20 participantes. Submeteu-se o GC ao ensino convencional em pacientes reais. O GE passou por quatro etapas: 1. fundamentação teórica, 2. manipulação do simulador, 3. prática clínica simulada e 4. avaliação nos pacientes reais. No GC, adotaram-se os seguintes passos: 1. fundamentação teórica, 2. treinamento direto em pacientes reais e 3. avaliação em pacientes reais. Após a intervenção de cada grupo, os dois grupos foram avaliados quanto à aprendizagem em 40 recém-nascidos da Fundação Santa Casa de Misericórdia do Pará, em Belém, no Pará.

Resultados: Na avaliação dos juízes em relação aos itens positivos para o simulador (design, similaridade, interesse, relevância, conteúdo, memorização, didática, reminiscência anterior, compreensão e aplicação), 49,2\% afirmaram que concordavamfortementee 44,4\% mencionaram apenas que concordavam. Nas questões negativas (dificuldade de entendimento, sobrecarga de informação, abstração, dificuldade de manuseio e clareza de operação), 40,0\% discordaram fortemente e 57,1\% discordaram. Os juízes concordaram em 94,9\% a favor do uso do simulador na educação médica. Porém, comparando os dois grupos de estudantes, em relação ao tempo de exame, os resultados não mostraram diferença estatisticamente significante $(p=0,29)$.

Conclusão: O manequim mostrou aplicabilidade na aprendizagem do TRV, com a vantagem de realizar o exame sem que o paciente real fosse incomodado. Palavras-chave: Prevenção de Doenças; Triagem Neonatal; Treinamento por Simulação.

1 Universidade do Estado do Pará, Belém, Pará, Brazil.

${ }^{2}$ Centro Universitário do Estado Pará, Belém, Pará, Brazil.

${ }^{3}$ Universidade Federal do Pará, Belém, Pará, Brazil.

Editor-in-Chief: Daniela Chiesa

Associate Editor: Roberto Zonato Esteves

Received on 06/23/20; Accepted on 11/26/20.| Evaluated by double blind review processes. 


\section{INTRODUCTION}

Humanized care during pregnancy, birth and for the newborns prioritizes good practice actions up to the second year of a child's life, including breastfeeding, vaccination and neonatal screening ${ }^{1}$. The standard screening consists of blood tests, the Red Reflex Test (RRT) or "eye test", the hearing screening or "little ear test" and congenital heart disease screening or "little heart test"2.

The ophthalmological screening, started at the maternity hospital, is generally performed using a direct ophthalmoscope ${ }^{3,4}$. The RRT was described in 1962 by Roland Brückne, who demonstrated the examination of the transillumination of the eyeball, as a procedure that was easy to apply and had good cost-benefit in the diagnosis of ocular pathologies ${ }^{5}$. This test consists of visualizing the retinal reflex. However, for the adequate projection of the ophthalmoscope light into the eyeball, it is necessary for the visual axis to be free, the media to be transparent (cornea, lens, vitreous) and the retina and optic nerve to be normal ${ }^{6}$. In addition to the pediatrician, the RRT can also be performed by an ophthalmologist or nurse trained in eye care?

According to the 2010 census of the Brazilian Institute of Geography and Statistics (IBGE, Instituto Brasileiro de Geografia e Estatística), $3.4 \%$ of the population has important visual impairment, and according to the World Health Organization (WHO) there are approximately 1.4 million children with eye disabilities worldwide, $90 \%$ of them living in developing countries. Approximately $80 \%$ of all causes of childhood blindness are preventable or treatable ${ }^{8}$.

At birth, the essential anatomical elements for visual processing already exist. However, they can only fully develop with adequate growth and stimulation, as the visual system is integrated with the neurological development ${ }^{8}$. Thus, if there is no adequate treatment for visual impairments up to 7 years of age, ophthalmic dysfunctions (amblyopia) may be irreversible ${ }^{3}$.

The main congenital ophthalmic diseases detected since birth are: congenital cataract (lens opacity), retinoblastoma (malignant tumor caused by the inactivation of both alleles of the tumor suppressor gene RB1 (retinoblastoma), retinochoroiditis (caused by congenital toxoplasmosis) and congenital glaucoma (increased intraocular pressure) ${ }^{5,9,10}$. These diseases, when diagnosed through the RRT and treated early, can increase the performance in visually-impaired children ${ }^{11}$.

In this regard, the RRT can reduce the social and economic impact for families and the government, through the implementation of courses in medical schools allowing students to learn how to screen for ocular pathologies in childhood. Teaching through simulation allows students and health professionals to acquire and improve clinical skills, since such technological instruments work as alternative means for practical learning in real-life patients ${ }^{12}$. Simulation improves the students' confidence, since there is no risk of causing damage to a human being while they do not master the correct performance of the procedure yet. Furthermore, simulators can also show results on student's performance, allowing the teacher to assess whether the student is ready to perform the procedure on real-life patients ${ }^{13}$.

Currently, there are direct and indirect eye simulators on the market, among them: Eye Exam Simulator ${ }^{\circledR}$ (created by Kyoto Kagashu Co) and VRmagic ${ }^{\circledast}$. Both are technological simulators used in academic training that show more realistic physiological and pathological characteristics commonly found in the test. Such simulators have shown promising results in medical training based on student assessment, but are not accessible $^{14}$.

Considering the abovementioned facts and that the time for teaching ophthalmology is being reduced in medical schools, it is justified to add new ophthalmological tools to the health professionals' training. Thus, the objective of this study was to develop a low-cost mannequin for the training of the RRT in newborns and to evaluate its educational effectiveness.

\section{METHODS}

\section{Dummy construction and operation}

The mannequin's development purpose is to provide practical training in RRT for health professionals. It consists of: 1) An electronic module responsible for the dummy's logical operation, allowing the setup of the exam parameters; and 2) a three-dimensional physical representation of the head of a human body between 0 and 6 months of age, measuring $12 \mathrm{~cm}$ wide and $14 \mathrm{~cm}$ high, with $2.5 \mathrm{~cm}$ diameter spherical eyeballs containing the light responsive circuit (Figures 1 and 2). It was conceived and developed using Blender ${ }^{\circledast}$ software and later printed in 3D with acrylonitrile butadiene styrene (ABS) filaments.

There is an electronic sensor at the bottom of the eye socket, which is responsible for capturing the intensity of the light beam produced by the ophthalmoscope. Therefore, it is possible to check if the light is reaching the right spot, equivalent to the anatomical positioning of the retina, so that the reflex appears, showing the preset pathology.

Regarding its basic function, the mannequin gives feedback as a light sign, from inside the eye, which can indicate: a physiological human eye, congenital cataract, leukocoria or retinoblastoma. 
Figure 1. Perspective view of the model

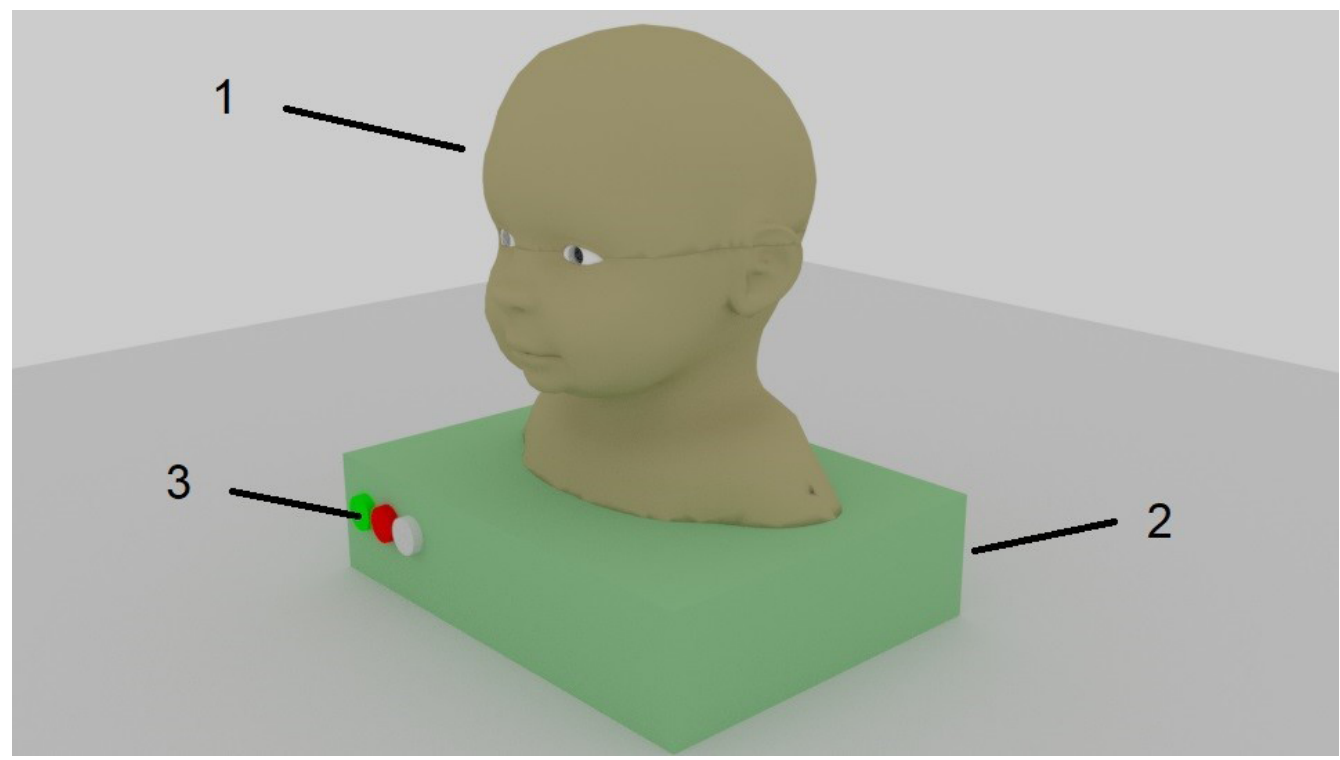

Note: (1) head; (2) housing for the electronic circuit; (3) control keys.

Inside the simulator's eyeballs, there are 4 LEDs (Light Emitting Diode) that measure 3 millimeters $(\mathrm{mm})$, with 2 red LEDs that represent the normal reflection, and two white LEDs that represent the retinoblastoma. Furthermore, there is a light intensity sensor (Light Dependent Resistor - LDR), which decreases the electrical resistance inversely proportional to the increase in light intensity, thus allowing the passage of the electric current necessary for the LEDs to work. The LEDs color selection depends on the configuration of potentiometers with an ON and OFF switch, which will select the desired color. Along with the activation of the LEDs, a buzzer (a type of speaker) that can be activated through a switch, can provide a sound feedback. The LEDs and the buzzer will only be activated when the student is able to correctly perform the RRT, that is, when there is enough luminous intensity in the LDR to close the circuit, which will only be possible when placing the ophthalmoscope's light beam upon the right spot.

Figure 2. Vision of the eye and its electronic components

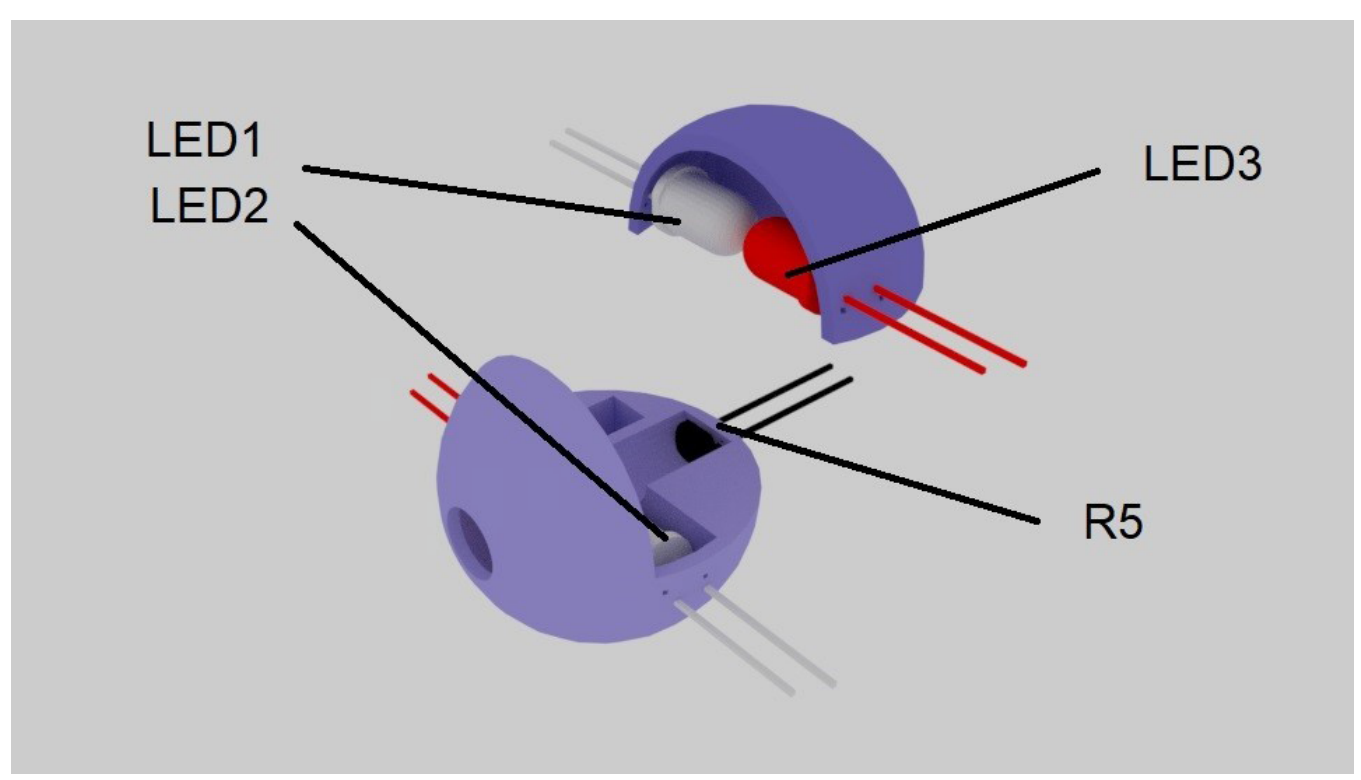

Note: LED1, LED2, LED3 (light emitters); R5 - light sensor (LDR). 
Figure 3. Graphical representation of the light stimulus in the electronic eye

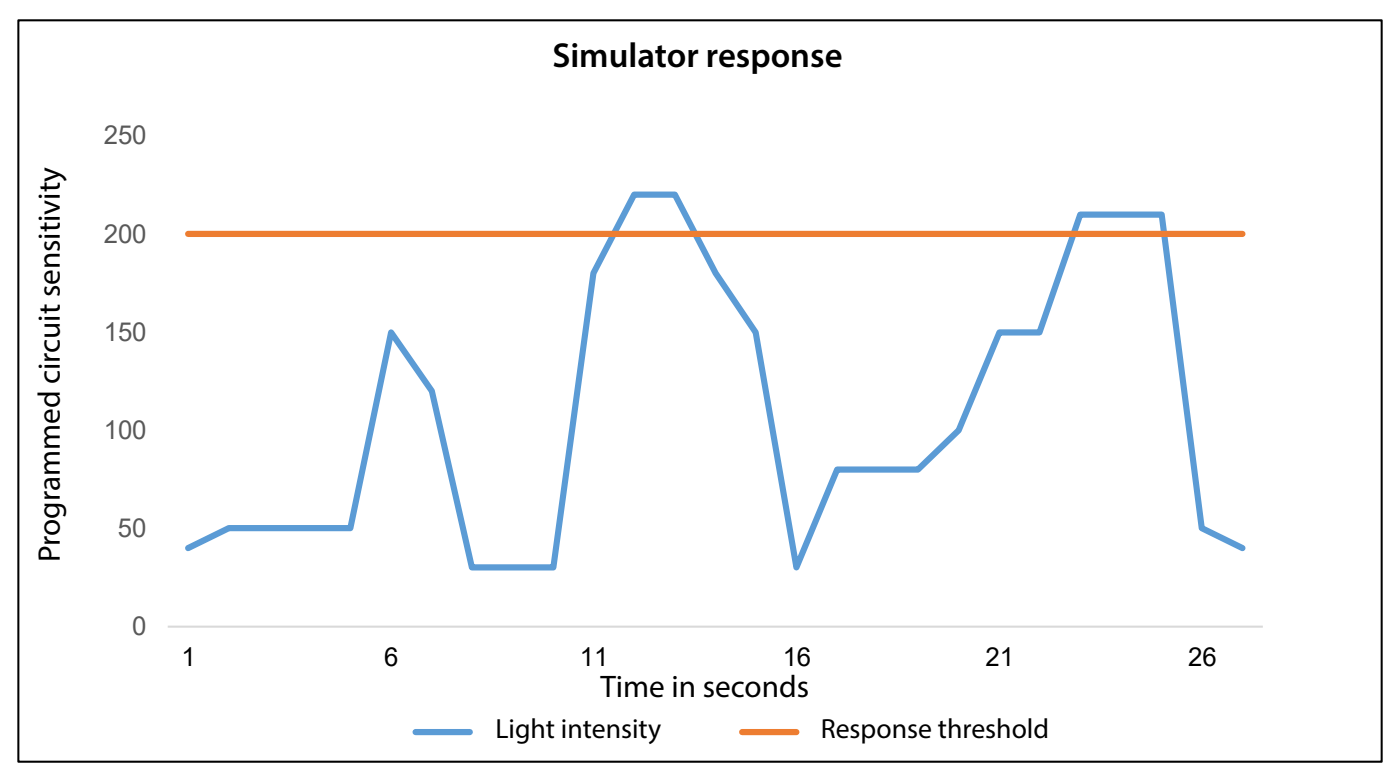

In addition to the light and sound feedback, there is also a visual feedback, previously programmed to establish a sensitivity limit (response threshold) indicating through a graph in the computer connected to the electronic module, which level of light intensity is being captured by the LDR. Thus, it helps the student to adjust the positioning of the ophthalmoscope, so that the light beam can reach the LDR correctly in order to obtain a response from the simulator.

The circuit was assembled and programmed using ARDUINO UNO - an electronic prototyping tool in free hardware that can be used to control several circuits or electronic components through a computer system interface.

\section{Mannequin Validation}

In order to capture the judges' perception of the relevance and educational suitability of the mannequin in RRT training, a convenience sample of six pediatricians and one ophthalmologist was selected, all with a minimum experience of 1 year in performing the RRT and active in the metropolitan region of Belém, in the State of Pará.

The mannequin was made available, fully operational, for handling by the specialists (judges) and, subsequently, a questionnaire for the assessment of educational games adapted from Software Quality Group ${ }^{15}$ was answered by them. The adapted questionnaire contains only items related to simulators. Items related to games in general were removed. This adaptation was necessary because simulators are considered a type of game, and the mannequin is a simulator. The questionnaire consisted of a total of 14 questions presented as a 5-point Likert scale, according to Level 1 (Reaction) of the Kirkpatrick Model for Training and Learning. The five following answers and their numerical values were available: strongly disagree (-2); disagree $(-1)$; neutral (0); agree (1); strongly agree (2) ${ }^{16}$.

This questionnaire aims to capture the judges' perception of the following aspects:

The simulator's interface is attractive;

(1) It was clear to me how the content of the Simulator is related to things I already knew about the eye test;

(2) I liked the simulator so much that I would like to learn even more about the subject covered by it; (4) The simulator's content is very relevant to my specialty;

(3) I was able to associate the simulator content to things I have seen, done or thought of;

(4) The teaching power of the simulator will be useful to me;

(5) The simulator was more difficult to understand than I would like;

(6) The simulator provided so much information that it was hard to identify and remember the important points;

(7) The simulator content is so abstract that it was difficult to keep my attention on it;

(8) The simulator activities were very difficult;

(9) I was unable to understand a good part of the content and behavior demonstrated during the simulation;

(10) After using the simulator, I can remember more information related to the eye test provided by it; 
(11) After using the simulator, I improved my understanding of the RRT technique and;

(12) After using the simulator, I feel that I can better apply what I have learned.

In addition, three open questions were also part of the questionnaire (1) What would you like to see added to this mannequin for future applications? (2) Name the items or elements that you liked the most in the mannequin? and (3) Name the items or elements that you liked the least in the mannequin? These, in turn, aimed to know the strengths, weaknesses and improvement suggestions for the simulator.

The study design adopted for the assessment of learning effectiveness, Kirkpatrick's Level 2 (Learning), comprised the distribution of participants into a control group (CG) and an experimental group (EG), followed by the application of a post-test after the corresponding interventions in each group: without the use of the mannequin and with the use of the mannequin, respectively.

An experimental study design with a CG and pre / post-test was not possible because the pre-test would require assessing the skills of the participants in real-life patients, without the participants' prior knowledge when performing the RRT, which could harm the patients.

In order to evaluate the learning effectiveness, 33 medical students, 5 pediatric residents, one general physician and one nurse who were not trained to perform the RRT participated in the study, totaling $n=40$. The participants' sample was defined according to the students' availability. The 40 participants were randomly assigned to the EG or the CG. Both groups were previously informed about the research project. The EG underwent simulation training using the mannequin, whereas the CG underwent direct training in real-life patients.

The EG went through 4 stages: 1) theoretical background; 2) handling of the simulator; 3 ) simulated clinical practice and; 4) evaluation in the real-life patients. The CG went through the following teaching methodological processes: 1) theoretical foundation; 2) direct training in real-life patients and; 4) practical evaluation in a real-life patient.

After the completion of the respective stages, both groups performed the RRT on 40 newborns at Santa Casa de Misericórdia of Pará Foundation Hospital. The students were evaluated regarding the proposed psychomotor skills, which were measured using the following variables: 1) Time and; 2) accuracy when performing the RRT. The time variable was measured from the time the student first held the ophthalmoscope until the sound feedback from the simulator was activated and the student's statement that he or she had adequately finished the examination, and the accuracy variable was measured by the exact correspondence between the pathology represented in the simulated reflex and the participants' response when observing the reflex.

Both groups used the simplified RRT approach published in the Community Eye Health Journal. In a dark environment, they used the direct ophthalmoscope, set to " 0 ", at a distance of $50 \mathrm{~cm}$ from the patient, to view the eyes together and, readjusted the optometry tool to a closer position, so that each patient's eye could be viewed separately.

\section{Ethical aspects}

The Human Research Ethics Committee (CEP) (Certificate 95152518.0.0000.5171) of Fundação Santa Casa de Misericórdia do Pará (FSCMPA) formally approved this research. The data collection took place from October 2018 to February 2019.

\section{RESULTS}

The demographic profile of the seven judges is: All are females, aged between 37 and 54 years old, still active in carrying out the RRT. Regarding the judges medical training, one was a specialist in ophthalmology and six in pediatrics, of which one had a Ph.D. and one had a Master's Degree.

Regarding the judges' evaluation questionnaire, our results showed that considering the positive aspects (design, similarity, interest, relevance, content, memorization, didactics, previous reminiscence, understanding and applicability) of the simulator, $49.2 \%$ answered 'strongly agree' and $44.4 \%$ answered 'agree'. Regarding the negative aspects (difficulty in understanding, excess of information, abstraction, difficulty in handling and clarity of operation) $40 \%$ answered 'strongly disagree', and $57.1 \%$, 'disagree'. Therefore, $94.9 \%$ of the judges' assessment was favorable to the mannequin.

Regarding the students who participated in the research, the results showed that all 20 students rom the EG were able to adequately handle and use the ophthalmoscope and perform the exam, using the correct technique on the patients. Considering the Accuracy variable, all participants in both CG and EG made the correct association between the simulated reflex and the correlated pathology. The average time in the EG to fully complete the exam was 27.45 seconds. On the other hand, in the CG the average time was 27.00 seconds.

The EG had a standard deviation $(\sigma)$ of 11.07 seconds and a variance of 122.68 seconds, while the CG had a $\sigma$ of 15.34 and a variance $\left(\sigma^{2}\right)$ of 235.33 . The Shapiro-Wilk normality test was applied to evaluate the time to complete the RRT in both groups. The EG values showed normal behavior ( $p$-value $=0.91$, while the CG did not show normal behavior ( $p$-value $=0.098$ ). Therefore, due to the non-normality of the CG time variable, the Mann-Whitney non-parametric statistical test was used $(p$-value $=0.49)$. 
Figure 4. Comparison of student group dispersion

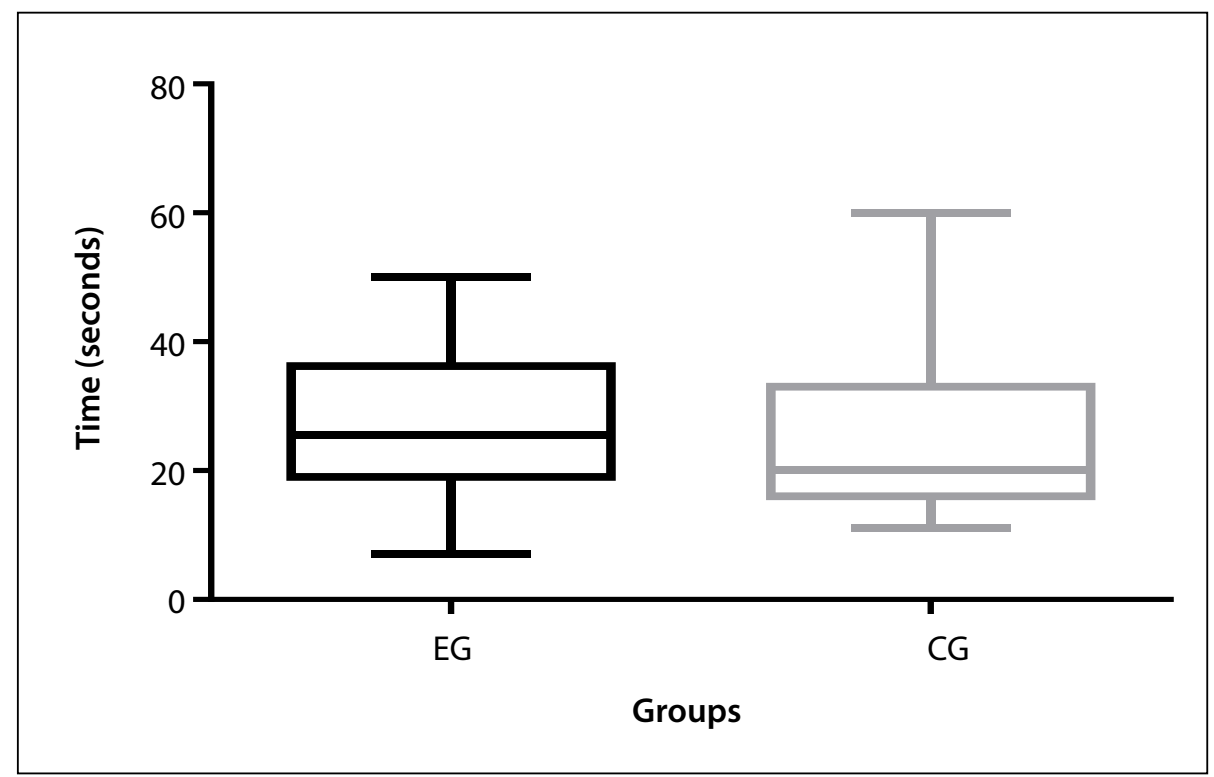

Note: Control Group (CG); Experimental Group (EG).

\section{DISCUSSION}

The number of participants in the sample of judges $(n=7)$ for the mannequin assessment is justified by the fact that the literature recommends at least six judges ${ }^{17}$, with the number seven being the safety margin for research. To test the reliability of the judges' questionnaires, Cronbach's alpha was applied, obtaining a result of 0.95 , considered to be excellent and, therefore, suitable for the research ${ }^{18}$.

Concerning the use of simulators for medical teaching, the literature points out several advantages, among them, the similarity of the simulation with real-life situations and the correction of some flaws in medical education ${ }^{19,20}$. Such evidence corroborates our results, since the judges pointed out the mannequin's precision and similarity with the real-life situation, and they all agreed and correlated it to situations they had already experienced. However, despite the "good" score regarding the question of similarity in open questions, the judges pointed out the need to improve the similarity of the mannequin to the reallife patient, adding features such as facial movements, blinking of the eyelids and skin color. Such suggestions for improvement will be added for the next version of the mannequin. Our results showed that the judges approved the usefulness of the simulator in their daily lives, since everyone agreed that the simulated content would be useful in their daily activities.

According to the literature, simulators need to be didactic and easy to handle ${ }^{14,21}$. In our study, $97.71 \%$ of the judges did not find any difficulty in using the simulator. The simulator allowed students to face a difficulty level similar to that found in patients, allowing teachers to obtain immediate feedback on the students' difficulties. However, despite showing promising results on the aesthetic evaluation characterized in the model, the judges suggested improvements to the simulator so that it resembles a real-life patient, either by adding facial and eyelid movements, or by giving it a more realistic skin color.

There was a debriefing after the training in the EG and the students emphasized the use of teaching simulators, which have several advantages, including the similarity with real-life situations, reducing the scarcity of learning in medical courses ${ }^{19}$. Also, the EG suggested that confidence may play an important role in improving RRT results in real-life patients.

Finally, our results were not statistically significant ( $p$-value $=0.49$ ) regarding the time spent to perform the RRT variable; therefore, the training to perform the RRT showed to be equally effective in the CG and EG after the interventions. However, there is a significant advantage in training with the simulator, as it does not require the direct handling of newborns, which can cause discomfort for the patients during the training of unexperienced students. Also, patients will not always be available for training, which can hinder the training of health professionals.

A possible bias in the research could be due to different professional training profiles (nurses, medical students, resident doctors in the field of pediatrics and general practitioners); however, we tried to divide them equally between the two groups and none of them had previous experience with RRT.

\section{CONCLUSION}

The study goals were achieved and the mannequin was considered suitable for teaching by the judges and the same efficacy of conventional teaching was obtained, with the advantage that it can be used multiple times without disturbing 
or causing injury to a real-life patient during an inexperienced student training. The research results point to a favorable outcome for the use of the red reflex test (RRT) simulator, highlighting that the use of simulators in medical learning is an important tool.

\section{AUTHORS' CONTRIBUTION}

Mauricio Leonardi da Silva Dias and Rafael Oliveira Chaves: designed the experiments. Mauricio Leonardi da Silva Dias, Danilo Jun Kadosaki and Igor Santos de Souza: collected the data. Ivete Furtado Ribeiro Caldas and Rafael Oliveira Chaves: analyzed the data. Joacy Pedro Franco David, Ivete Furtado Ribeiro Caldas and Rafael Oliveira Chaves: wrote the manuscript.

\section{CONFLICTS OF INTEREST}

The authors declare no conflicts of interest.

\section{SOURCES OF FUNDING}

The authors declare no sources of funding for this research.

\section{REFERENCES}

1. Montori VM, Hargraves I, McNellis RJ, Ganiats TG, Genevro J, Miller T, et al. The care and learn model: a practice and research model for improving healthcare quality and outcomes. J Gen Intern Med. 2019;34(1):154-8. doi: 10.1007/s11606-018-4737-7.

2. Baldino VMCL, Eckert GU, Rossatto J, Wagner MB. Red reflex test at the maternity hospital: results from a tertiary hospital and variables associated with inconclusive test results. J Pediatr. 2019;1-7. doi: 10.1016/j. jped.2019.08.007.

3. Loh AR, Chiang MF. Pediatric Vision Screening. Pediatrics in Review. 2018;39(5):225-33 doi: 10.1542/pir.2016-0191.

4. Nascimento GCC, Gagliardo HGRG. Atenção à saúde ocular de crianças com alterações no desenvolvimento em serviços de intervenção precoce: barreiras e facilitadores. Rev Bras Oftalmol. 2016;75(5):370-5. doi: 10.5935/0034-7280.20160074

5. Cagliari PZ, Silva JC, Veras TN, Vieira CEF, Bertelli L, Ramos MC. Alterações detectadas pelo teste do reflexo vermelho. Arq Catarin Med. 2016;45(3):48-57.

6. Jain $\mathrm{P}$, Kothari MT, Gode V. The opportunistic screening of refractive errors in school-going children by pediatrician using enhanced Brückner test. Indian J Ophthalmol. 2016;64(10):733-6. doi: 10.4103/0301-4738.19502.
7. Raoof Naz, Dai S. Red reflex screening in New Zealand: a large survey of practices and attitudes in the Auckland region. NZ Med J. 2016;129(1438):39.

8. Zimmermann A, Carvalho KMM, Atihe C, Zimmermann SMV, Ribeiro VLM Visual development in children aged 0 to 6 years. Arq Bras Oftalmol. 2019;82(3):173-5. doi: 10.5935/0004-2749.20190034.

9. Haddad MAO, Lobato FJC, Sampaio MW, Kara-José N. Pediatric and adolescent population with visual impairment: study of 385 cases. Clinics. 2006;82(3):173-5. doi: 10.1590/S1807-59322006000300009.

10. Ortiz MV, Dunkel IJ. Retinoblastoma. Journal of child neurology. 2016;31(2):227-36. doi: 10.1177/0883073815587943.

11. Simkin SK, Misra SL, Battin M, McGhee CNJ. Prospective observational study of universal newborn eye screening in a hospital and community setting in New Zealand. BMJ Pediatrics Open. 2019;376(3):1-6. doi: 10.1136/bmjpo-2018-000376.

12. Flores $C D, B e z, M R$, Bruno, RM. O uso de simuladores no ensino da medicina. RBIE. 2014;22(02):98-108. doi: 10.5753/rbie.2014.22.02.98.

13. Al-Elq AH. Simulation-based medical teaching and learning. J Family Community Med. 2010;17(1):35-40. doi: 10.4103/1319-1683.68787.

14. Ricci LH, Ferraz CA. Modelos de simulação aplicados ao ensino prático e aprimoramento de habilidades em oftalmoscopia direta e indireta: uma revisão. Arquivos Brasileiros de Oftalmologia, 2014;77(5):334-8. doi: 10.5935/0004-2749.20140084.

15. Savi R. GQS - Software Quality Group. 2020 [access in 20 nov 2020]. Available from: http://www.gqs.ufsc.br/avaliacao-de-jogos-educacionais Subscription required.

16. Summers R, Wang S, Abd-El-Khalick F, Said Z. Comparing Likert Scale Functionality Across Culturally and Linguistically Diverse Groups in Science Education Research: an Illustration Using Qatari Students' Responses to an Attitude Toward Science Survey. International Journal of Science and Mathematics Education. 2019;17(5):885-903. doi: 10.1007/ s10763-018-9889-8.

17. Lee Y, Moon M. Utilization and Content Evaluation of Mobile Applications for Pregnancy, Bith, and Child Care. Healthc Inform Res. 2016;22(2):73-80. doi: 10.4258/hir.2016.22.2.73

18. RODRÍGUEZ-RODRÍGUEZ, Julio; REGUANT-ÁLVAREZ, Mercedes. Calcular la fiabilitat d'un qüestionari o escala mitjançant I'SPSS: el coeficient alfa de Cronbach. REIRE. 2020;13(2):1-13.

19. Kouzmitcheva E, Grover SA, Berenbaum T, Ali A, Atkinson A, Yeh EA Evaluation of an Ophthalmoscopy Simulator to Teach Funduscopy Skills to Pediatric Residents. Can J Neurol Sci. 2018:45(3):320-4.

20. Martins T, Costa AL, Helene O, Schor P, Martins R. Low-cost model for teaching ophthalmoscopy. Medical education. 2015;49:528. doi: 10.1111/ medu.12703.

21. Ting DSW, Sim SSKP, Yau CWL, Rosman M, Aw AT, San Yeo IY. Ophthalmology simulation for undergraduate and postgraduate clinical education. Int J Ophthalmol. 2016;9(6):920-4. doi: 10.18240/ijo.2016.06.22.

22. Philippin H. How to test for the red reflex in a child. Community Eye Health. 2014;27(86):36. 